\title{
Correction to: Social Entrepreneurship Strategies by the Middle Eastern Governments: A Review
}

\author{
Amir Forouharfar
}

\section{Correction to:}

Chapter 7 in: N. Faghih, M. R. Zali (eds.), Entrepreneurship

Ecosystem in the Middle East and North Africa (MENA),

Contributions to Management Science,

https://doi.org/10.1007/978-3-319-75913-5_7

The original version of Chap. 7 was inadvertently published with incorrect reference citations.

Page 190: para 1, line 15: 'ECOSOC 2013' has been replaced by 'TIMUN 2013'

Page 203: para 1, line 17: 'ECOSOC 2016' has been replaced by 'GIMUN 2016'

Reference list: The references 'ECOSOC 2013' and 'ECOSOC 2016' have been replaced by 'TIMUN 2013' and 'GIMUN 2016' respectively. 